\title{
One new Cyclosa species, and the first record of C. sachikoae Tanikawa, 1992 from China (Aranei: Araneidae)
}

\section{Новый вид пауков рода Cyclosa и первое указание C. sacbikoae Tanikawa, 1992 дмя Китая(Aranei: Araneidae)}

\author{
Beibei Zhou, Feng Zhang* \\ Б. Жоу, Ф. Жань*
}

\begin{abstract}
The Key Laboratory of Invertebrate Systematics and Application, College of Life Sciences, Hebei University, Baoding 071002, P. R. China.

* Corresponding author. E-mail: dudu06042001@163.com
\end{abstract}

KEY WORDS: spider, Araneae, taxonomy, description, Hainan Island.

КЛЮЧЕВЫЕ СЛОВА: паук, Аraneae, таксономия, описание, Хайнань.

ABSTRACT: A new species, Cyclosa rostrata sp. $\mathrm{n}$. is described based on the holotype and paratype males from Hainan. Cyclosa sachikoae Tanikawa, 1992, originally described from Okinawa Prefecture and Kyushu Island (Japan) is recorded from China (Hainan Island) for the first time.

How to cite this article: Zhou B., Zhang F. 2017. One new Cyclosa species, and the first record of $C$. sachikoae Tanikawa, 1992 from China (Aranei: Araneidae) // Arthropoda Selecta. Vol.26. No.4. P.335340. doi: 10.15298/arthsel.26.4.09

РЕЗЮМЕ. Описан новый вид паука-крестовика Cyclosa rostrata sp. n. на основании двух самцов из острова Хайнань. Cyclosa sachikoae Tanikawa, 1992, вид ранее известный из островов Кюсю и Окинава, впервые отмечен в Китае на острове Хайнань.

\section{Introduction}

Araneidae Clerck, 1757, the third largest spider family, currently includes 173 genera and 3123 extant species [World Spider Catalog, 2017]. The taxonomy of Araneidae is relatively well studied in China and adjacent Japan due to several revisions and monographs [Yin et al., 1997; Tanikawa, 2009]. To date, 46 genera and 374 species have been reported from China [Li, Lin, 2016].

The genus Cyclosa Menge 1866, currently contains 171 species worldwide, among them, 39 species were recorded from China [World Spider Catalog, 2017]. Hainan Island, situated at the southernmost part of China, is considered as a tropical biodiversity rich region [Tong et al., 2008]. Six species of Cyclosa have been reported from Hainan: C. cucurbitoria (Yin et al., 1990), C. dives Simon, 1877, C. informis Yin, Zhu et
Wang, 1995, C. minora Yin, Zhu et Wang, 1995, C. mulmeinensis (Thorell, 1887), C. parangdives Barrion et al., 2013 [Li, Lin, 2016].

While examining spider collections from Hainan Island, China, we recognized $C$. sachikoae Tanikawa, 1992, a species previously known from Okinawa only [Tanikawa, 2009] as well as new species. The main goal of this paper is to provide a description of the new species and a redescription of $C$. sachikoae.

\section{Materials and Methods}

All specimens are preserved in $75 \%$ alcohol and were examined, drawn and measured with a Leica M205A stereomicroscope equipped with an Abbe drawing device. Photographs were taken using a Leica M205A stereomicroscope equipped with a DFC550 CCD camera. All measurements are given in millimeters. Carapace length was measured medially from the anterior to the posterior margin. The total length is the sum of the carapace and abdomen length, regardless of the petiolus. Eye diameters were measured at the widest point. Leg measurements are shown as: total length (femur, patella, tibia, metatarsus, tarsus). The type specimens are deposited in the Museum of Hebei University, Baoding, China (MHBU).

Abbreviations used in the text: AER - anterior eye row; ALE - anterior lateral eyes; AME - anterior median eyes; $\mathrm{C}$ - conductor; $\mathrm{E}$ - embolus; MA median apophysis; MOA, median ocular area; PER posterior eye row; PLE - posterior lateral eyes; PME - posterior median eyes; PM — paramedian apophysis; S - scape; ST — spermatheca; TA - terminal apophysis.

Museum abbreviations: MHBU — Museum of Hebei University, Baoding, China; NSMT - National Science Museum, Tokyo, Japan. 

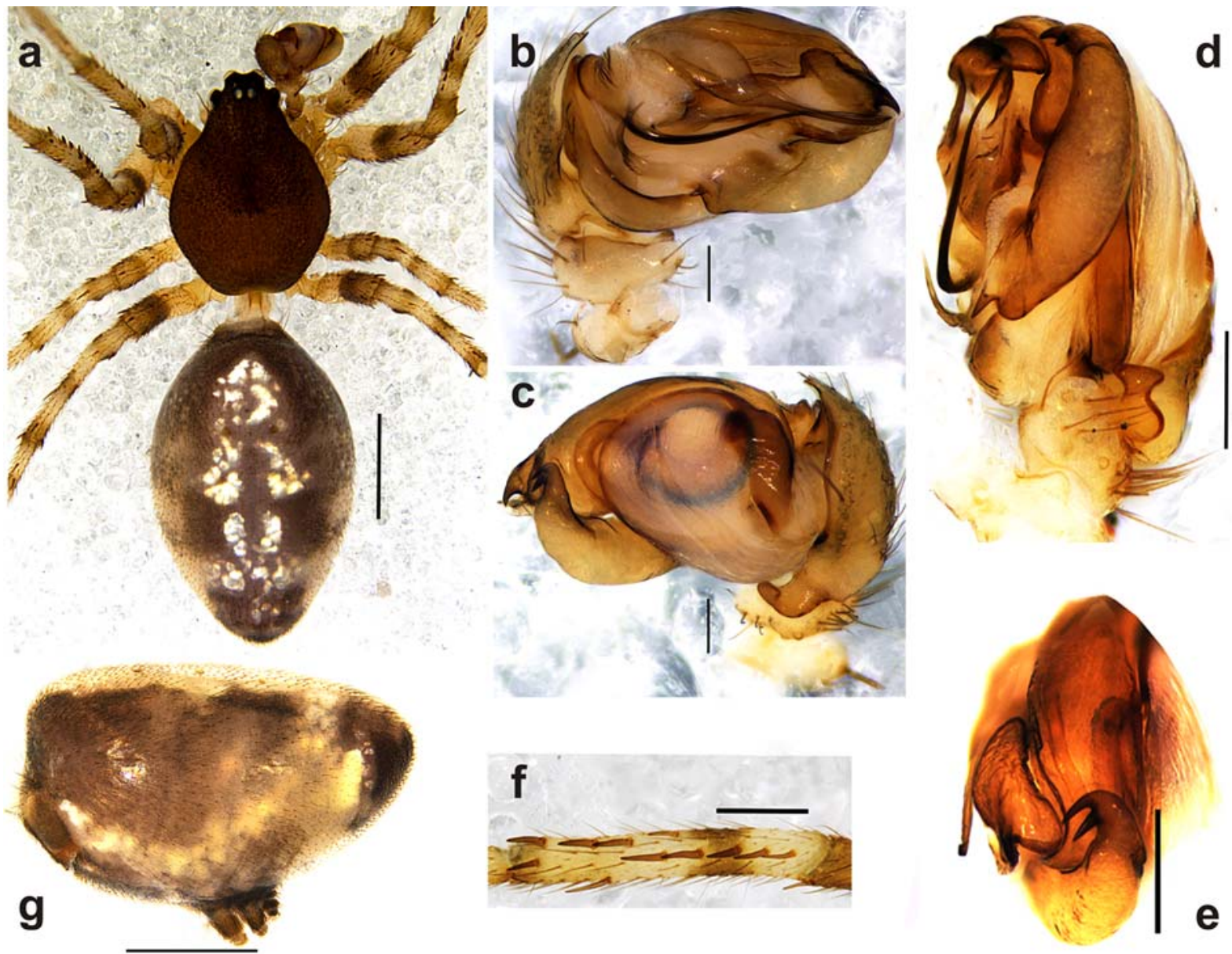

Fig. 1. Male of Cyclosa rostrata sp.n. A - habitus, dorsal; b - left palp, prolateral; c - same, retrolateral; d - same, axial view; e median apophysis (distal part), axial view; f — tibia II, prolateral; g — abdomen, lateral. Scale bars: $0.5 \mathrm{~mm}(\mathrm{a}, \mathrm{g}) ; 0.1 \mathrm{~mm}$ (b-e); $0.2 \mathrm{~mm}$ (f).

Рис. 1. Самец Cyclosa rostrata sp.n. А — габитус, сверху; b - левая пальпа, пролатерально; с — то же, ретролатерально; d то же, снизу; е - медиальный апофиз (дистальная часть), снизу; f - голень II , пролатерально; g - брюшко, сбоку. Масштаб: 0,5 мм (a, g); 0,1 мм (b-e); 0,2 мм (f).

\section{Taxonomy}

\section{Cyclosa rostrata sp.n.}

Figs 1-2.

TYPE MATERIAL. Holotype $\sigma^{\top}$, CHINA: Hainan Island, Qiongzhong County, Limu Mountains, $19^{\circ} 10^{\prime} \mathrm{N}, 109^{\circ} 45^{\prime} \mathrm{E}, 18.08 .2007$, Feng Zhang leg.; Paratype: $1 \sigma^{7}$, CHINA: Hainan Island: Changjiang County, Bawangling National Nature Reserve $\left(19^{\circ} 04^{\prime} \mathrm{N}, 109^{\circ} 08^{\prime} \mathrm{E}\right)$, 20.05.2009, Xiaoxiao Zhang leg. (MHBU).

ETYMOLOGY. The specific name is derived from the Latin word "rostratus", referring to the shape of the conductor of the male palp.

DIAGNOSIS. The male of this new species is most similar to C. norihisai Tanikawa, 1992 in having a similar embolus and median apophysis, but can be distinguished by: 1) the posterior end of the abdomen is pointed (Fig. 1a), vs. oval in C. norihisai [Tanikawa, 1992: 43, fig. 104]; 2) the paramedian apophysis is visible in prolateral view (Fig. 1b) vs. hidden in $C$. norihisai [Tanikawa, 1992: 43, fig. 107]; 3) the median apophysis is large and distally bifurcated (Fig. 1e), but smaller in C. norihisai [Tanikawa, 1992: 43, fig. 105];
4) the shape of the conductor in prolateral view also differs from that of C. norihisai (Fig. 1b; Tanikawa, 1992: 43, fig. 107).

DESCRIPTION. Male. Holotype (Fig. 1a): total length 3.79; carapace 1.56 long, 1.16 wide; abdomen 2.23 long, 1.47 wide. Carapace brown. Both eye rows recurved from above, AER longer than PER. Eye sizes and interdistances: AME 0.12, ALE 0.07, PME 0.09, PLE 0.08; AME-AME 0.07, AME-ALE 0.08, PMEPME 0.04, PME-PLE 0.14; MOA length 0.26, anterior width 0.30 , posterior width 0.17 . Clypeus height 0.27 . Chelicerae slightly yellow, promargin with 4 and retromargin with 2 teeth. Endites pale brown, inner margins yellowish. Labium pale brown, distally yellowish. Sternum dark brown. Legs yellowish with brown annulations. Leg measurements: I $4.10(1.5,0.47,0.95,0.83$, $0.34)$; II 4.02 (1.16, 0.48, 0.97, 0.94, 0.47); III 2.98 $(1.06,0.37,0.61,0.53,0.41)$; IV 4.29(1.57, 0.48, 0.94, $0.90,0.43)$. Leg formula: 4123 . Abdomen oval, posteriorly straight, longer than wide; dorsum pale brown, with silvery markings anteriorly and posteriorly; venter pale brown, with silvery markings (Fig. 1g). 

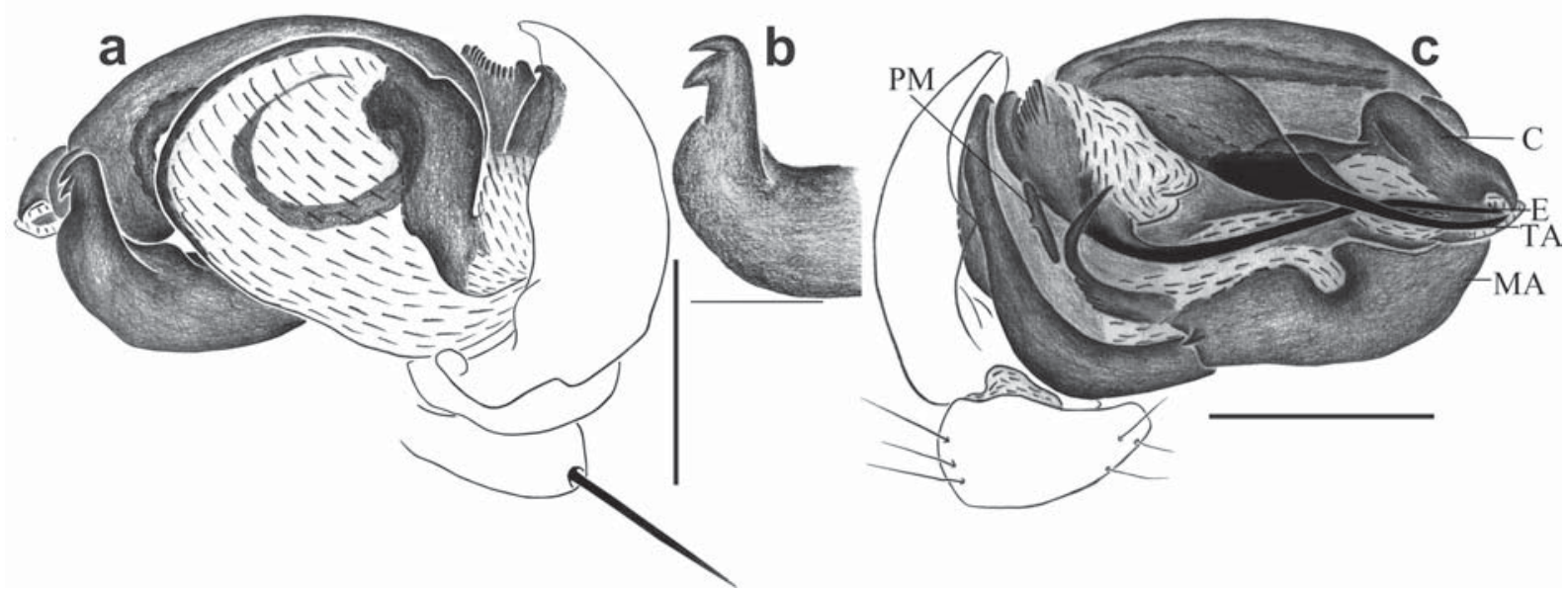

Fig. 2. Male left palp of Cyclosa rostrata sp.n. A - retrolateral; b - median apophysis (distal part), retrolateral; $\mathrm{c}$ - prolateral. Scale bars: $0.25 \mathrm{~mm}(\mathrm{a}, \mathrm{c}) ; 0.1 \mathrm{~mm}$ (b).

Рис. 2. Левая пальпа самца Cyclosa rostrata sp.n. А - ретролатерально; b - медиальный апофиз (дистально), ретролатерально; с - пролатерально. Масштаб: 0,25 мм (a, c); 0,1 мм (b).

Palp as in Figs 1b-e, 2a-c; median apophysis thick, distally bent and bifurcated, basally with a digitiform lamella and a small tooth; paramedian apophysis visible in prolateral view; embolus flagelliform.

Female: unknown.

DISTRIBUTION. Type locality only.

Cyclosa sachikoae Tanikawa, 1992 Figs 3-6.

Cyclosa sachikoae Tanikawa, 1992: 60, f. 182-189 ( ( 7 + $)$; Tanikawa, 2007: 61, f. 117-119, 539-540 (O'P); Tanikawa et al., 2008: 69, f. 5 ()); Tanikawa, 2009: 439, f. 120-121 (

MATERIAL EXAMINED. $10^{7}$, CHINA: Hainan Island: Wuzhi Mountain, Shuiman Town, $18^{\circ} 54^{\prime} \mathrm{N}, 109^{\circ} 42^{\prime} \mathrm{E}, 14.08 .2007$, Feng Zhang leg. (MHBU); $2 \mathrm{O}^{\top} \mathrm{O}^{\top} 10$ 우, same locality, 16.11.2008, Guangxin Han \& Shengtao Guo leg. (MHBU).
DIAGNOSIS. This species resembles $C$. quinqueguttata (Thorell, 1881) known from Southeast Asia, but can be distinguished from the latter by: 1) the median apophysis has 2 teeth close to each other (Figs 3c, 4d) vs. distant from each other in C. quinqueguttata [Tanikawa, 1992: 63, fig. 195]; 2) the distal part of epigynal scape is wide and tongue-shaped $v s$. narrow (Figs 5a, 6c) and almost triangular in C. quinqueguttata [Tanikawa, 1992: 63, fig. 193].

REDESCRIPTION. Male. Total length 2.70: carapace 1.43 long, 1.17 wide; abdomen 1.43 long, 1.12wide. Carapace (Figs 3a, 4a) dark brown. Eye sizes and interdistances: AME 0.08, ALE 0.05, PME 0.08, PLE 0.05; AME-AME 0.10, AME-ALE 0.08, PME-PME 0.03, PME-PLE 0.15; MOA length 0.23,

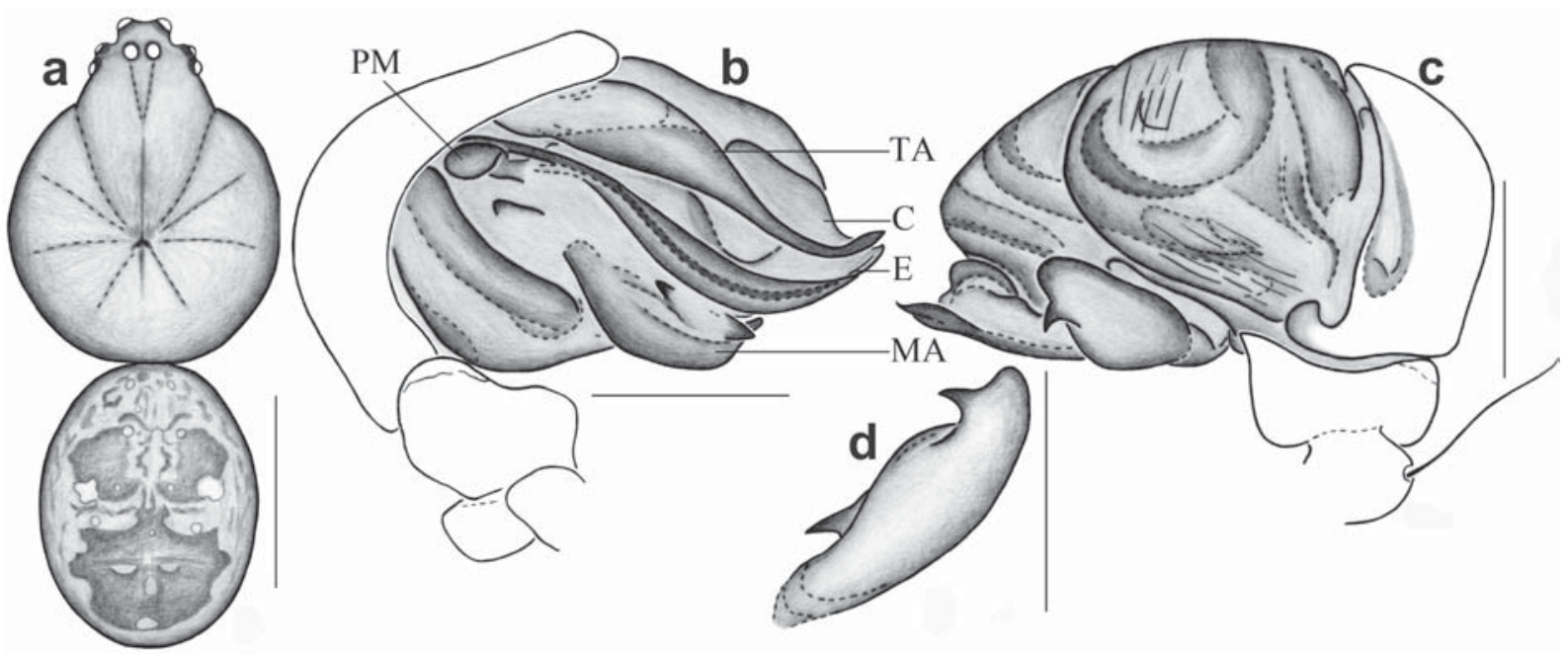

Fig. 3. Male of Cyclosa sachikoae. A — habitus, dorsal; b - tibia II, prolateral; c - median apophysis; $\mathrm{d}$ - left palp, prolateral; e same, retrolateral. Scale bars: $0.5 \mathrm{~mm}(\mathrm{a}) ; 0.1 \mathrm{~mm}(\mathrm{~b}-\mathrm{e})$.

Рис. 3. Самец Cyclosa sachikoae. А - габитус, сверху; b - голень II, пролатерально; с — медиальный апофиз; $\mathrm{d}$ - левая пальпа, пролатерально; е - то же, ретролатерально. Масштаб: 0,5 мм (a); 0,1 мм (b-e). 

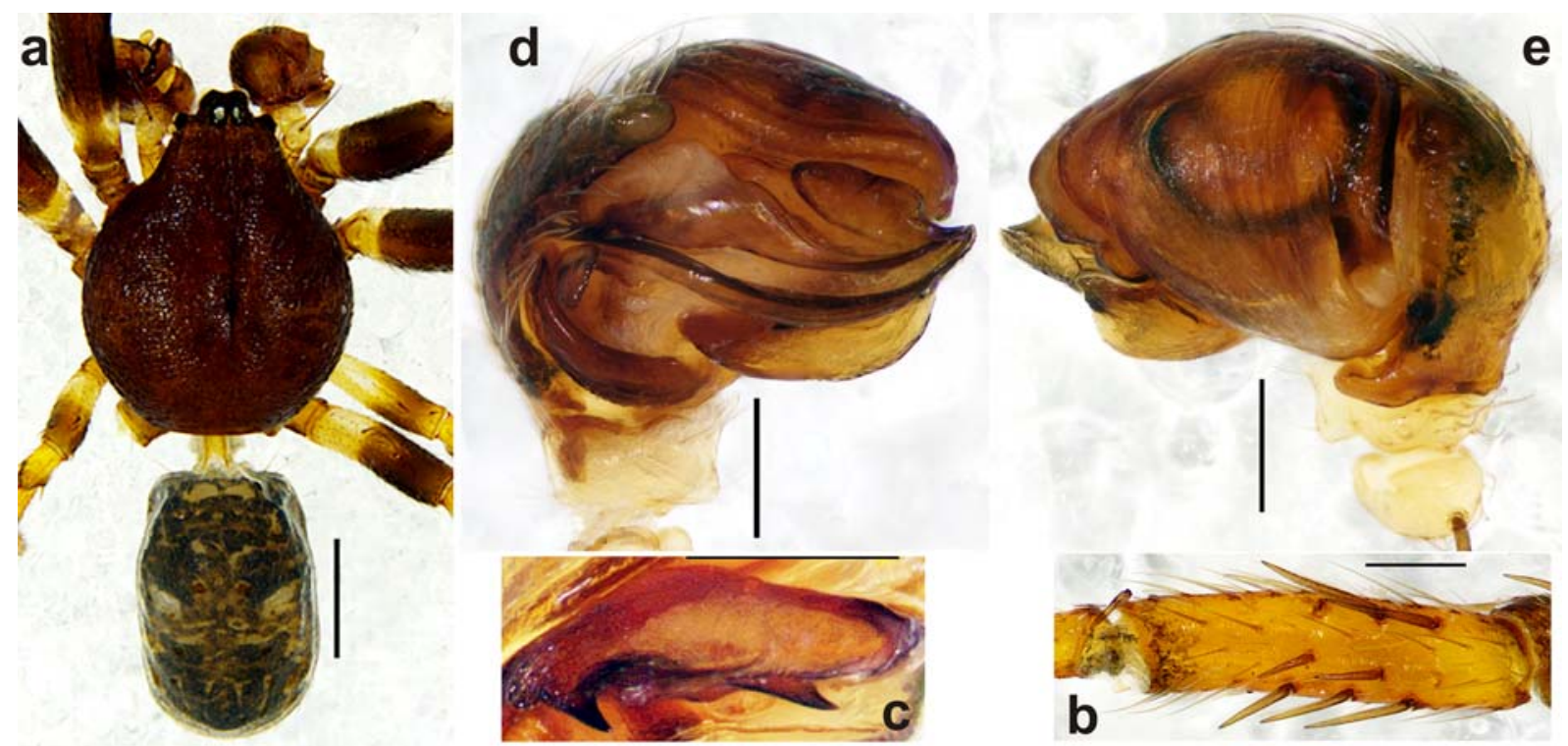

Fig. 4. Male of Cyclosa sachikoae. A - male habitus, dorsal; b - left palp, prolateral; c - same, retrolateral; d — median apophysis. Scale bars: $1 \mathrm{~mm}(\mathrm{a}) ; 0.2 \mathrm{~mm}(\mathrm{~b}-\mathrm{d})$

Рис. 4. Самец Cyclosa sachikoae. А — габитус, сверху; b - левая пальпа, пролатерально; с — то же, ретролатерально; $\mathrm{d}$ медиальный апофиз. Масштаб: 1 мм (a); 0,2 мм (b-d).

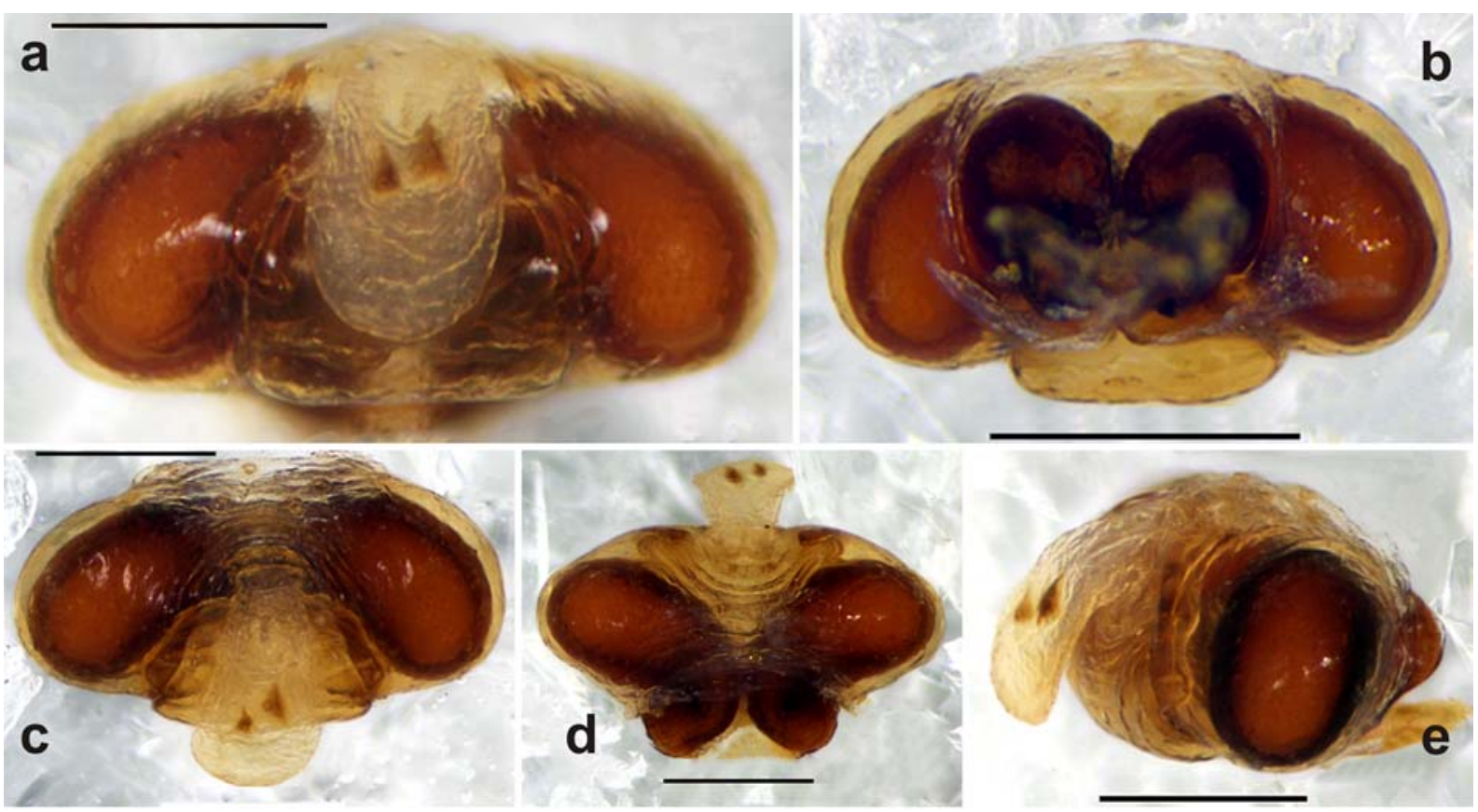

Fig. 5. Epigyne of Cyclosa sachikoae. A — ventral; b — dorsal; c — anterior-ventral; d - posterior; e — lateral. Scale bars: $0.1 \mathrm{~mm}$ (a, c-e); $0.2 \mathrm{~mm}$ (b).

Рис. 5. Эпигина Cyclosa sachikoae. А - снизу; b - сверху; с - спереди-снизу; d - сзади; е — сбоку. Масштаб: 0,1 мм (a, сe); 0,2 мм (b).

anterior width 0.23 , posterior width 0.18 . Chelicerae yellow brown, promargin with 2 teeth and retromargin with 3 teeth. Endites dark brown, inner margins yellow. Labium dark brown, distally yellow. Sternum dark brown. Legs yellow with dark brown annulations. Leg measurements: I $3.26(1.07,0.46,0.66,0.66,0.41)$; II $2.96(0.97,0.41,0.51,0.66,0.41)$; III $1.90(0.61,0.26$,
$0.31,0.41,0.31)$; IV3.16 (1.07, 0.36, 0.66, 0.66, 0.41). Leg formula: 1423. Abdomen oval in dorsal view (Figs. $3 \mathrm{a}, 4 \mathrm{a})$, longer than wide, dark brown; dorsum with black markings and several white spots.

Palp as in Figs $3 \mathrm{c}-\mathrm{e}, 4 \mathrm{~b}-\mathrm{d}$; concealed by the edge of the conductor; median apophysis with two small teeth, one at terminal part and another in the middle; 


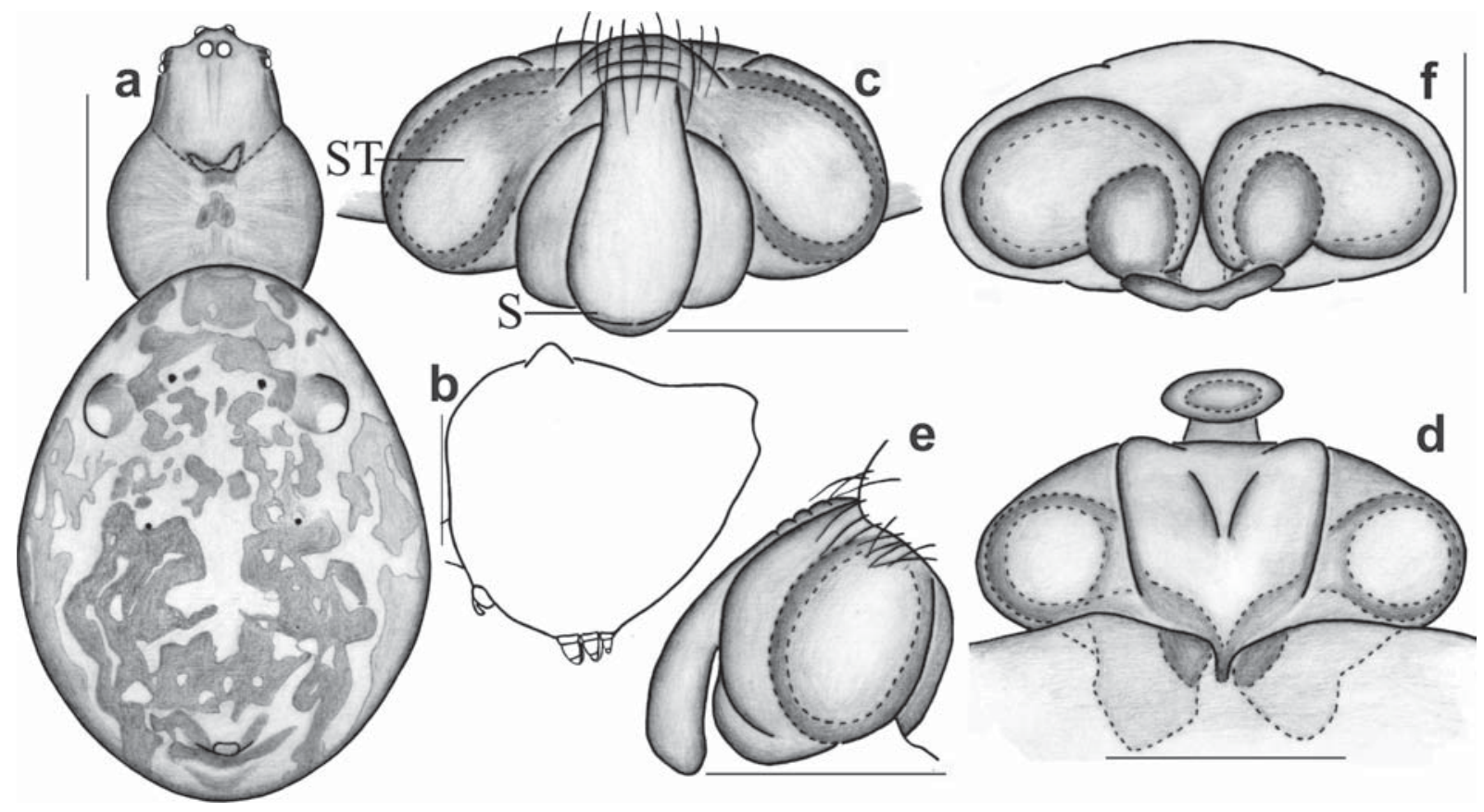

Fig. 6. Female of Cyclosa sachikoae. A — habitus, dorsal; b — abdomen, lateral; c — epigyne, ventral; d — same, posterior; e — same, lateral; $\mathrm{f}$ - same, dorsal. Scale bars: $1 \mathrm{~mm}(\mathrm{a}-\mathrm{b}) ; 0.2 \mathrm{~mm}(\mathrm{c}-\mathrm{f})$.

Рис. 6. Самка Cyclosa sachikoae. А - габитус, сверху; b - брюшко, сбоку; с — эпигина, снизу; d - то же, сзади; е - то же, сбоку; f - то же, сверху. Масштаб: 1 мм (a-b); 0,2 мм (c-f).

paramedian apophysis visible in prolateral view, embolus filiform.

Female. Total length 3.98: carapace 1.38 long, 1.12 wide; abdomen 2.81 long, 2.19 wide. Eye sizes and interdistances: AME 0.08, ALE 0.08, PME 0.08, PLE 0.08; AME-AME 0.08, AME-ALE 0.13, PME-PME 0.03, PME-PLE 0.18; MOA length 0.20, anterior width 0.23 , posterior width 0.18 . Promargin with 3 teeth and retromargin with 2 teeth. Leg measurements: I 3.73 $(1.22,0.56,0.77,0.77,0.41)$; II 3.26 (1.02, 0.51, 0.66, $0.66,0.41)$; III $2.36(0.97,0.26,0.41,0.41,0.31)$; IV 3.36 (1.02, 0.46, 0.71, 0.71, 0.46). Leg formula: 1423 . Abdomen anteriorly with a pair of dorsal tubercles, and with a protuberance at the posterior end (Figs. 6a, b). Other characters as in male.

Epigyne as in Figs 5a-e, 6c-f; scape tongue-shaped, not wrinkled, thin, 2 times longer than wide; the width of the epigynal plate almost twice the length; scape shorter than epigynal plate width, spermathecae oval.

Size variations: Males 2.38-2.70; females 3.215.37 .

DISTRIBUTION. Hainan (China) and southern Japan (Kyushu and Iriomotejima Island, Okinawa).

REMARK. This species is recorded from China for the first time. The shape of the female abdomen is slightly different from the original description, with the posterior end being slightly bifurcated. No differences have been found in the shape of the epigyne and palp.

ACKNOWLEDGEMENTS. We are grateful to Guangxin Han, Shengtao Guo and Xiaoxiao Zhang for collecting valuable specimens. Yuri Marusik is thanked for his comments that improved the manuscript. Akio Tanikawa (Tokyo, Japan) provided us information about the distribution of Cyclosa sachikoae in Japan. English of the final draft was kindly checked by Sarah Crews (San Francisco, USA). This work was supported by the National Natural Science Foundation of China (No. 31672261).

\section{References}

Li S.Q., Lin Y.C. 2016. Species Catalogue of China: Volume 2 Animals: Invertebrates. Arachnida: Araneae. Beijing: Science Press. 549 pp.

Tanikawa A. 1992. A revisional study of the Japanese spiders of the genus Cyclosa (Araneae: Araneidae) // Acta arachnologica. Tokyo. Vol.41. P.11-85.

Tanikawa A. 2007. An Identification Guide to the Japanese Spiders of the Families Araneidae, Nephilidae and Tetragnathidae. Japan: Osaka: Arachnological Society. $121 \mathrm{pp}$.

Tanikawa A., Ikeda Y., Yoshio M. 2008. The first description of the male of Cyclosa alba considering the partial sequence of mitochondrial CO1 gene // Acta Arachnologica. Vol.57. P.6770.

Tanikawa A. 2009. Araneidae // Ono H. (ed.). The Spiders of Japan with keys to the families and genera and illustrations of the species. Kanagawa: Tokai University Press. P.420-463.

Tong Y.F., Li S.Q. 2008. Four new species of six-eyed pholcid spiders (Araneae: Pholcidae) from Hainan Island, China // The Raffles Bulletin of Zoology. Vol.56. P.45-53.

World Spider Catalog Version 18. 2017. World Spider Catalog. Natural History Museum Bern, online at http://wsc.nmbe.ch (accessed on 22 September 2017).

Song D.X., Zhu M.S., Chen J. 1999. The Spiders of China. Shijiazhuang: Hebei Science \& Technology Publishing House. 640 pp. 
Yin C.M., Wang J.F., Zhu M.S., Xie L.P., Peng X.J., Bao Y.H. 1997. Fauna Sinica: Arachnida: Araneae: Araneidae. Beijing: Science Press. 460 pp.

Responsible editor Yu.M. Marusik 